\title{
Peacekeeping in a bad neighbour- hood: The Economic Community of West African States (ECOWAS) in peace and security in West Africa
}

\section{David J. Francis ${ }^{*}$}

\section{Abstract}

Is there any role for regional organisations in the maintenance of international peace and security and if so, how effective are they? This question has polarised the debate on the role and potential contribution of regional intergovernmental collective security organisations in the maintenance of international peace and security in the post-Cold War period. Some scholars argue that regional organisations play only a limited role and that even when they do so, it is often in pursuit of their political or strategic self-interests. On the other hand, some academics and policy practitioners are of the view that regional organisations not only have a role to play but have emerged as a viable framework for the maintenance of regional peace and security. In the process, they have 'rescued' the global institution, the United Nations, in its mandate to maintain international peace and security. The case of the West African peacekeeping and conflict stabilisation interventions and regional deployments have been cited as a reflection of this development, despite its many problems and challenges. If this is the case, what has been the role and contribution of ECOWAS (the Economic Community of

* David J. Francis is Professor of African Peace and Conflict Studies at the University of Bradford. This article is made possible due to the research support of the London School of Economics-based Crisis States Project. 
West African States) integration in regional peace, security, conflict prevention, management and resolution?

\section{Introduction}

This article critically outlines the role and contribution of ECOWAS (the Economic Community of West African States) regionalism to peace and security and examines the core factors that determine its effectiveness. It will do so by exploring how the West African sub-region has emerged as the new theatre of violent intra-state conflicts and a 'bad neighbourhood' in Africa. To understand the imperatives for the expansion of the sub-regional economic co-operation entity into security regionalism, concomitant with the evolution of a regional peacekeeping and conflict management capability, it is important to start with a political economy analysis of West Africa. Building on this, the article examines the experience of ECOWAS regional peacekeeping, peace support operators and conflict stabilisation interventions in Liberia, Sierra Leone, Guinea Bissau and Côte d'Ivoire. The primary focus is to provide an understanding of the emergence of a regional peace, security and conflict management architecture in West Africa and how this has developed from ad hoc improvisation in response to the challenges of violent conflicts in the sub-region and to the evolution of a nascent regional co-operative ethos underpinned by the 'Try Africa First' approach.

The core argument of this article is that the West African sub-region is a violent and 'bad neighbourhood' with weak and collapsed states that 'habitually' intervene (by both military and non-military means) in member states. Therefore, one cannot expect too much from ECOWAS in terms of effectiveness in peace and security, ${ }^{1}$ in particular, if we define 'peace' as not only the mere absence of war but also the elimination of all conditions that cause human suffering such as structural, cultural and physical violence. In addition, if we define 'security' in military and non-military terms, it becomes obvious that any pretence of

1 From a neo-realist perspective, John Mearsheimer (1994:33) argues that 'institutions have minimal influence on state behaviour and thus hold little promise of promoting stability and inter-state co-operation in the post-Cold War world'. Robert Keohane (1994) outlines two important approaches to understanding the role of international institutions and the potential contribution of multilateral organisations to the maintenance of international peace and security. 
ECOWAS to effectiveness in peace and security is far above and beyond the capacity of the regional organisation. ${ }^{2}$ In simple terms, are we not demanding too much of a regional organisation to deliver the multi-faceted and multi-level dimensions of peace and security? If this is the case, this article therefore focuses only on one aspect of ECOWAS' peace and security, i.e. ECOWAS Ceasefire Monitoring Group (ECOMOG) military operations and in particular the ECOWAS-ECOMOG ad hoc peacekeeping and peace support operations in the sub-region. This focus is important because it is in this area that ECOWAS has registered some positive impact on regional peace and security. Furthermore, the specific focus on ECOMOG's military and peacekeeping activities provides the basis to evaluate the wider effectiveness of ECOWAS in peace and security.

\section{'Bad neighbourhood' and the regionalisation of civil wars: Political economy of West Africa}

The popular, if not, iconic image of West Africa, as presented by the international media, is that of a region plagued by bloody civil wars and state collapse with drug-crazed, gun-totting child soldiers on the rampage - all in the midst of humanitarian disaster. In fact, the West African sub-region was portrayed in 1994 by Robert Kaplan (1994) as having the potential to become the 'real strategic danger' threatening international peace and security. The question is: why West Africa? The 'geographical expression' that is described as West Africa is a diverse and complex geo-political and social construction, with an estimated population of 235 million (2003), accounting for approximately 32 per cent of Africa's total population. The region comprises sixteen geographically proximate and contiguous states that have emerged as a distinct political and socio-economic entity and a territorial sub-system. The diversity of West Africa is reflected in its political history with an Anglophone, Francophone and Lusophone colonial

2 See Ernst Haas (1994), David J. Francis (2006a and 2006b). In general, traditional co-operation theories such as neo-liberal institutionalism (including the functional integration theories of the 1940s and 50s, the neo-functional regional integration theory of the 1950s and 60s, and the interdependence/complex interdependence theory of the 1970s) have argued in several ways that international institutions and organisations can facilitate inter-state (security) co-operation or limit the constraining effects of the 'anarchic international system' (Keohane 1982). 


\section{David J. Francis}

divide, ${ }^{3}$ and with socio-cultural, ethnic and linguistic differences. The colonial legacies and their accompanying diverse political and administrative orientations of West African states have often led to political disputes and tensions, to the extent that political leaders are suspicious of the intentions of their counterparts if they are not from the same 'colonial bloc'. The colonial divide and diversity have often played themselves out in the arena of West African intra-regional co-operation and international affairs. The similarity shared by the majority of West African countries is that they are generally described as least developed or underdeveloped states in terms of their level of economic development and social progress (United Nations Development Programme 2006).

In addition, European imperialism and colonialism in West Africa have left a legacy of external dependence with largely cash crop, agrarian and extractivebased economies relying heavily on Multinational Corporations (MNCs) for the exploitation of these strategic resources. Agricultural products are the primary foreign exchange earners for the majority of the countries, whilst others depend on strategic mineral resources such as diamonds, gold, bauxite, iron ore, tin, zinc, copper, uranium, liquefied natural gas and oil (Nigeria is a leading oil producer). Despite the vast mineral resource endowment, the sub-region has not been able to convert its strategic resources into sustainable economic growth, development and social progress.

The West African sub-region, since political independence in the late 1950s and early 1960s, has experimented with a variety of political systems of governance ranging from multi-party democratic politics to single-party civilian authoritarian governments and military dictatorships. In fact, the sub-region has the highest incidence of military coups and interventions in civilian politics in Africa (Francis 2001:11). The combined effects of the end of the Cold War and the negative effects of globalisation, coupled with the nature of domestic politics based on neo-patrimonialism, have led to state collapse and civil wars as in Liberia, Sierra Leone, Guinea Bissau, Mali, Niger and Côte d'Ivoire, hence

3 The Anglophone countries include: Sierra Leone, Ghana, The Gambia, Liberia and Nigeria. The Francophone States include: Guinea, Senegal, Mali, Niger, Côte d'Ivoire, Burkina Faso, Mauritania, Benin and Togo; whilst the Lusophone countries comprise Guinea Bissau and Cape Verde. 
Kaplan's warning that the sub-region was emerging as the new threat and 'strategic danger' to international peace and security.

An important dimension of the nature of wars and armed conflicts in West Africa is the regionalisation of domestic civil wars. The majority of the wars have spilled over into neighbouring countries and the armed conflicts are not just localised within state borders. The regional dimensions and dynamics of violence often fuel and sustain these wars through the activities of the shadow economy and 'peace spoilers', i.e. those diverse interests that benefit from the exploitation of the war economies and would do anything to ensure the prolongation of the war. The involvement in the regionalised war economy of all the warring factions, who exploit the dysfunctional formal economy, the shifting alliances during armed conflict, and the long-standing regional political affiliations and informal commercial networks, all create the firm impression of a 'bad neighbourhood'. Moreover the military and security threats in West Africa are not only limited to wars and armed conflicts, but also include criminal violence, intra-communal violence, mercenaries or 'guns for hire' - including Private Military Companies (PMCs) and Private Security Companies (PSCs) - plying their military expertise in the sub-region's conflict zones, and the proliferation of small arms and light weapons.

\section{Evolution of ECOWAS integration and security regionalism}

The Economic Community of West African States (ECOWAS) has emerged as the most developed and complex sub-regional organisation in Africa. It was originally chartered as a regional integration and co-operation grouping on 28 May 1975 with customs union and common market objectives. ECOWAS comprises fifteen countries at different levels of development and at diverse stages of state formation and nation building. ${ }^{4} \mathrm{~A}$ number of reasons were

4 ECOWAS initially comprised 16 member states including Sierra Leone, Liberia, Nigeria, The Gambia, Senegal, Ghana, Togo, Benin, Côte d'Ivoire, Cape Verde, Guinea, Niger, Guinea Bissau, Burkina Faso, and Mali. Mauritania withdrew its membership of the Organisation in 2000 for a variety of political and strategic reasons. 


\section{David J. Francis}

responsible for the formation of ECOWAS. From an economic perspective, formation of ECOWAS integration was perceived as a national and regional development strategy. Politically, ECOWAS regionalism was assumed to serve as an instrument of foreign policy and a collective political bargaining bloc. Since its creation, the focus of ECOWAS integration and co-operation has been driven by developmental regionalism underpinned by market integration based on the liberal economic development strategy.

Though the primary objective for the creation of ECOWAS was the attainment of regional economic development, the challenges of regional security threats have been a constant concern of ECOWAS countries. The domestic and external threats to state security and regime survival led to the signing of the 1978 Protocol on Non-Aggression and the 1981 Protocol on Mutual Assistance in Defence. Political leaders such as Leopold Sedar Senghor of Senegal had argued that 'development cannot be secured in a climate of insecurity' and that hence there was the imperative that 'we must among ourselves, establish a genuine West African solidarity pact to guard against external aggression' (Adebi 2002:115). It was recognition of the link between regional peace, security and development that led to the establishment of the Francophone mutual defence pact, the Accord de Non-Aggression et d'Assistance en Matières de Defence (ANAD).

An additional problem is that security was perceived by ECOWAS leaders in the traditional framework of military, national level-oriented, external security threats. This traditional conception of security perceived in external terms only focused on armed activities and the use, or threat of the use, of military force engineered and actively supported from outside the region, and with the potential to endanger regional peace and security. Domestic security threats from ethnoreligious conflicts, bad governance, political repression and insecurity created by the states' military and security apparatus, were never considered as part of the threats to national and regional security. In effect, both the 1978 and 1981 defence and military protocols were merely 'regime protection' strategies to serve the interests of ECOWAS leaders and to 'insure' them against both external and internal security threats. These defence protocols, therefore, provided a window of opportunity to clamp down, with military assistance from Community members, on internal opposition and coup attempts and to deal with political 
instability or support for political dissidents in neighbouring countries. Though the case could be made that the defence protocols created the basis for ECOWAS to take on regional collective security and peacekeeping capability, it was in reality a mechanism for regime security and survival.

Institutionally, ECOWAS is governed by seven key structures including: the Authority of Heads of State and Government; the Council of Ministers; the Community Parliament; the Economic and Social Council; the Community Court of Justice; the Commission, and the ECOWAS Bank for Investment and Development (EBID). In addition, eight specialised agencies have been established to facilitate the work of ECOWAS integration, including the West African Gender Development Centre (EGDC), West African Health Organisation (WAHO), West African Monetary Agency (WAMA), Water Resource Co-ordination Unit (WRCU), West African Power Pool (WAPP) and the ECOWAS Brown Card. In fact, the new ECOWAS Commission has created the office of the Commissioner for Political Affairs, Peace and Security (PAPS), with three operational departments including: Political Affairs, Early Warning/Observation Monitoring Centre (ECOWARN), and Peacekeeping and Security. However it is important to recognise that some of these key governance institutions and specialised agencies are merely normative intentions because they are yet to be fully operational. In January 2007 the ECOWAS Secretariat was transformed into a Commission as part of a wider institutional reform of the Community. It is obvious that this transformation into a Commission is a mere African imitation of the European Union (EU) model. Given the track record of the ECOWAS Secretariat, it is doubtful whether this name change and institutional tinkering will have any meaningful impact on the peace, security and development lives of the people in the ECOWAS region. Notwithstanding the challenges of ECOWAS economic integration, the 1990s saw the development of a formal peace and security architecture to facilitate regional peacekeeping, peace support operations, and conflict management interventions. The ECOWAS Mechanism for Conflict Prevention, Management, Resolution, Peacekeeping and Security of 1999 is the first formal attempt to outline the institutional provision and legal mandate for ECOWAS response to peace and security. A notable feature of the mechanism is that it attempts to shift 
the ECOWAS emphasis from conflict management (reactive and fire-brigade type interventions) to conflict prevention.

\section{ECOWAS peacekeeping and conflict stabilisation interventions in a 'bad neighbourhood'}

It was the bloody civil war in Liberia in 1989 that forced ECOWAS leaders to face the fact that they could no longer run away from the reality of developing a regional mechanism for peace, security and conflict management. The civil war in Liberia resulted in devastating regional consequences in terms of massive influx of refugees into neighbouring countries, large scale displacement of the internal population, gross violations of human rights, mass killings and widespread destruction of property. The bloody and violent civil war created a humanitarian disaster that directly threatened regional peace and security.

The civil war was led by Charles Taylor, leader of the National Patriotic Front of Liberia (NPFL), against the brutal dictatorship of President Samuel Doe. Charles Taylor's insurgency was supported by other West African states such as Côte d'Ivoire and Burkina Faso, and by Colonel Gaddaffi of Libya. But the outbreak of the Liberian civil war did not attract immediate intervention by the international community, despite the unfolding humanitarian catastrophe. The United States (US), which had a special relationship with Liberia, was, during this period, preoccupied with the United Nations-backed international coalition in the Gulf war against Saddam Hussein's Iraq. The United Nations (UN) was also over-burdened with its new post-Cold War responsibilities for the maintenance of international peace and security. It was this perception of international neglect of Africa that created the opportunity for the sub-regional hegemon, Nigeria, to assume political and military leadership in the management and resolution of the Liberian conflict.

\section{Liberia: ECOMOG I}

In an attempt to resolve the Liberian civil war, the ECOWAS summit in Banjul, The Gambia, established the ECOWAS Standing Mediation Committee (SMC) on the recommendation of the Nigerian military Head of State, General Ibrahim 
Babangida, as a regional mechanism to 'settle disputes and conflict situations within the Community ... and to look into inter-state dispute and conflicts which have a disruptive effect on normal life within the member states and on the smooth functioning of the Community' (Nwachukwu 1991:104). This ad hoc committee ${ }^{5}$ was mandated with the responsibility to mediate the resolution of the Liberian conflict. The beleaguered Liberian president, Samuel Doe, requested ECOWAS to send an intervention peacekeeping force into Liberia to forestall the increasing violence and tension and to ensure peaceful transitional environment (Francis 2001:436). It was the decision of the ECOWAS Authority at an extra-session of the Community in August 1990 to accept the request of the embattled Liberian president that led to the formal establishment of ECOMOG. It is important to note that the mandate of ECOMOG was framed in the spirit of traditional peacekeeping or First Generation peacekeeping, whereby a peacekeeping force is deployed as a neutral inter-positionary force between two opposing national armies or warring factions, acting as a confidence building mechanism to prevent relapse into further conflict. But the Liberian conflict was a complex political emergency with different warring factions fighting to control the collapsed state, in which the very basic functions of the state and its governing institutions could not be performed. Therefore, when the ECOMOG peacekeeping and intervention force landed in August 1990, there was no peace to keep, no cease-fire to monitor nor the consent from the main warring faction, the NPFL, because there was no viable constituted government to grant consent. In such a complex conflict situation, traditional peacekeeping was of limited relevance, and ECOMOG could not serve as a neutral inter-positionary force. ECOMOG inevitably became embroiled in the conflict. What was needed in Liberia was something akin to a UN Charter Chapter VII peace enforcement mandate because of the multi-dimensional nature of the peacekeeping and peace support operation challenges. ${ }^{7}$

5 SMC comprised Gambia, Ghana, Mali, Nigeria, Togo, and later included Sierra Leone and Guinea.

6 With reference to ECOWAS Standing Mediation Committee 1990.

7 Multi-dimensional post-Cold War peacekeeping include delivery of humanitarian assistance, protection of safe havens, monitoring and protection of human rights, organising and supervising elections, repatriation of refugees. It has been described as Second Generation peacekeeping or complex peacekeeping. 


\section{David J. Francis}

Between 1991 and 1997, the ECOWAS Peace Plan for Liberia led to the deployment of the UN Observer Mission in Liberia (UNOMIL) with a Chapter VI peacekeeping mandate based on co-deployment with ECOMOG, the signing of several peace agreements such as Yamoussoukro (1991), Cotonuo (1993) and the Abuja Peace Accords $(1995,1996)$. These developments, under the auspices of ECOWAS, UN and OAU (Organisation of African Unity) led to the holding of general and presidential elections in 1997, which were won by Charles Taylor's political party. The new Nigerian military head of state, General Sanni Abacha, was quick to recognise that without Taylor in the presidency of Liberia, there would be no peace. Though the elections were certified as free and fair by international observers, the reality was that it was an enforced peace that sacrificed issues of justice, reconciliation and fundamental grievances for the sake of a 'quick-fix' stability and fragile peace.

By 1999 the fragile peace in Liberia unravelled and the situation was further aggravated by the violent and bloody civil war in neighbouring Sierra Leone. The military attacks by anti-Taylor forces such as LURD (Liberian United for Reconstruction and Development) and MODEL (Movement for Democracy in Liberia) and mounting international pressures on Taylor by the US, ECOWAS, AU (African Union) and other key players led to a negotiated political settlement whereby President Taylor was forced to leave office on 11 August 2003. The Accra Comprehensive Peace Agreement provided for the formation of a transitional government and the exile of Taylor to Nigeria, whilst an international arrest warrant was issued by the UN-backed Special Court for war crimes charges in Sierra Leone. Taylor is currently facing trial at The Hague for war crimes.

To stabilise the security situation on the ground, US Marines and a contingent of ECOMIL (ECOWAS Mission in Liberia) troops were deployed after the exit of President Taylor. With an improved security situation on the ground, the UN Security Council adopted resolution 1509 which established a 15000 strong United Nations Mission in Liberia (UNMIL) with a Chapter VII peace enforcement mandate. The robust peacekeeping mandate was created in recognition of the complex political emergency situation in Liberia and the multi-dimensional nature of the peacekeeping challenges in post-war Liberia. 


\section{Sierra Leone: ECOMOG II}

It did not take long for the spill over effect of the Liberian Civil War to be manifest in neighbouring Sierra Leone, when the Corporal Foday Sankoh-led Revolutionary United Front led a war against the All Peoples Congress (APC) party government under the leadership of President Joseph Momoh. For a variety of reasons, the RUF rebellion was directly supported by Charles Taylor's NPFL, and covertly by other West Africa states such as Burkina Faso and Côte d'Ivoire, and Gaddaffi's Libya. The Sankoh-Taylor axis was based on the understanding that the success of the Liberian civil war would be used as a staging post for the overthrow of the APC regime in Sierra Leone through rebel insurgence and that strategic mineral resources such as diamonds would be used to finance the war. Therefore in 1990 Charles Taylor opposed the use of the territory of Sierra Leone to facilitate the military operations of ECOMOG in Liberia. Taylor perceived this as a major obstacle in his bid to secure the presidency in Liberia, and therefore threatened to attack Sierra Leone. ${ }^{8}$

It was the Armed Forces Revolutionary Council (AFRC) military coup led by Major Johnny Paul Koroma in May 1997 which overthrew the democratic government of President Kabbah that led to the ECOWAS and ECOMOG intervention in Sierra Leone.

The ECOWAS Peace Plan for Sierra Leone facilitated the signing of peace agreements such as Abidjan (1996), Conakry (1997) and Lomé (1999) and the deployment of UN peacekeeping missions including UN Observer Mission in Sierra Leone (UNOMSIL, 1998) and UN Mission in Sierra Leone (UNAMSIL, 1999). It was the involvement of the Nigerian-led ECOMOG II peace enforcement intervention that led to the overthrow of the AFRC military junta and the reinstatement of the government of President Kabbah in March 1998.

The Nigerian-led pro-democracy intervention in Sierra Leone was not only an important development in the political history of West Africa, but also had important implications for the international relations of ECOWAS and Africa in

8 See Francis 2001:110-112 for Taylor's media interview with the BBC Focus on Africa Programme on 1 November 1990, in which he was threatening to attack Sierra Leone for allowing its territory to be used for ECOMOG military operations. 


\section{David J. Francis}

general, because this was the first time that a military junta was overthrown in the name of democracy and constitutional order. The 'defence of democracy' in Sierra Leone or the attempt to do an American-style reinstatement of Haitian President Aristide in 1994, was nothing more than an attempt to enhance the damaged domestic and international image of Nigeria and in particular its military head of state General Abacha. The Nigerian military leadership under Generals Babangida and Abacha had subverted the democratic wishes of the Nigerian populace in annulling the results of 12 June 1993 general elections, clamped down on all democratic forces in the country, and caused the suspension of Nigeria from the Commonwealth in 1995. Without democratic credentials and legitimacy, why would General Abacha defend democracy denied in his own country? The Sierra Leone civil war provided the opportunity for the Nigerian military leader to burnish his battered international image and to establish his domestic democratic credentials. The Sierra Leone pro-democracy adventure by General Abacha was a ploy to further strengthen his international credibility and silence his critics, in particular after the political settlement of the Liberian civil war in 1997. The co-deployment of ECOMOG and UNAMSIL, supported by the British military intervention (Operation Palliser), created the enabling environment for the end of the civil war in 2001 with a power-sharing government.

\section{Guinea Bissau: ECOMOG III}

The outbreak of the civil war in Guinea Bissau in 1998 dragged ECOMOG into another regional peacekeeping and conflict management adventure. This civil war threatened the national security of the immediate neighbouring states, i.e. Senegal and Guinea, as well as regional peace and security, further reinforcing the impression of a bad neighbourhood. Both Guinea and Senegal were already hosting thousands of refugees from the conflicts in Liberia and Sierra Leone, and could not contemplate the consequences of yet another massive influx of refugees from Bissau.

President Vieira asked Nigeria, the then chair of the ECOWAS Authority, for military intervention to help resolve the conflict. In response to Vieira's request, ECOWAS Foreign and Defence ministers meeting in Abidjan in July 1998 
recommended the following: 'affirmed support of the democratically elected government of President Vieira and the need to restore his authority, employing a combination of dialogue, sanctions and use of force' (Olawunmi 1998:17), and the establishment of an ECOWAS Committee of Seven to implement the decisions. By the time the committee could meet in August in Accra, Ghana, the Community of Portuguese Speaking Countries (CPLP) had already brokered a truce between the warring factions. Subsequently, a joint ECOWAS-CPLP meeting in August in Praia, Cape Verde, led to the signing of a ceasefire agreement between the parties and provided for the deployment of an international observer force to monitor the agreement. The Praia agreement was, however, shattered by continuous fighting for control of the capital city. The ECOWAS peace mediation led to the signing of a ceasefire agreement and the deployment of the Togolese-led ECOMOG III peacekeeping force in December 1998, with a Chapter VI mandate.

The continued fighting between Vieira and the army commander virtually ended the mission of ECOMOG III, as the peacekeeping force refused to intervene in the fight for the control of the capital city or to assist Vieira's forces. In addition, logistical and financial difficulties prevented the continued deployment of ECOMOG in Guinea Bissau. This therefore paved the way for the intervention of the UN by authorising the deployment of an assistance mission, the UN Peacebuilding Support Office in Guinea Bissau (UNOGBIS), which became operational in June 1999. The mandate of UNOGBIS was to promote national reconciliation, and assist in organising and supervising parliamentary and presidential elections (UN Security Council 1999). In Guinea Bissau, the UN only intervened after a rather messy and problematic ECOMOG intervention. The UN appointed a Special Representative of the Secretary-General (SRSG) to work with ECOWAS and, in collaboration with external partners, organised and supervised general and presidential elections.

\section{Côte d'Ivoire: ECOMOG IV}

The bad neighbourhood dynamics and the spill over of civil conflicts in West Africa became evident in Côte d'Ivoire, long described as the 'oasis of peace and prosperity' in a region troubled by armed conflicts and political instability. 


\section{David J. Francis}

In December 1999, a military coup was led by the army chief, General Robert Guei, against President Bedie. General Guei, after a period of rule, organised democratic elections and his attempt to rig the result of the elections in his favour led to a people's revolution that forced him out of power. Laurent Gbagbo of the Front Populaire Ivorien (FPI) was declared winner of the October 2000 general elections. There were recurrent political clashes and instability between Guei and Gbagbo's supporters, which eventually led to a military mutiny in September 2002 and the outbreak of a civil war. The country became divided in two, the pro-government south controlled by government forces and supporters, and the North-West controlled by three rebel factions including the main group, Movement Patriotique de Côte d'Ivoire (MPCI), Ivorian Popular Movement for the Far West (MPIGO, comprising largely the Western Yacouba ethnic group) and the so-called New Forces - Movement for Justice and Peace (MJP).

The French-brokered peace talks led to the signing of the Linas-Marcoussis Accord in January 2003 providing for a ceasefire which was largely favoured by the rebels, but not by government supporters. The peace agreement provided for the formation of a transitional power-sharing government that would be inclusive of both opposition political parties and rebel factions. The ceasefire paved the way for UN-authorised deployment of French troops and ECOWAS peacekeepers and the establishment of the UN Mission in Côte d'Ivoire (MINUCI). The ECOWAS Peace Plan for Côte d'Ivoire facilitated the deployment of ECOMICI (ECOMOG IV) - a largely Francophone dominated peacekeeping mission - and the formation of a power-sharing government between the New Forces rebels and the government.

\section{What factors determine ECOWAS effectiveness in peace and security?}

A range of factors determine ECOWAS effectiveness in peace and security. These factors include: the regionalisation of domestic civil wars and how this serves as the impetus for action by regional leaders; political viability of the states and the willingness to lend themselves to the difficult and expensive activities of maintaining regional peace and security; organisational mandate and in 
particular, clarifying the appropriateness of the mandate for peacekeeping interventions; the destructive role of peace 'spoilers' including the exploitation of war economies and how these constrain the effectiveness of the regional organisation. For the purposes of this article we have decided to focus on four key factors that may provide a better appreciation of the effectiveness of ECOWAS.

\section{Geo-politics and the challenges of common foreign and security policies}

A major determinant for effectiveness of any regional organisation is the nature of geo-politics and the extent to which West African states have developed common foreign and security policies, and in particular 'dependable expectation of peaceful change' (Deutsch, Burrell and Kann 1957:6). Historically, ECOWAS integration has been plagued by the geo-politics of Anglophone, Francophone and Lusophone divides. In addition, the internal, external and conflict/ co-operation (amity-enmity) logics of regional integration have constantly played themselves out in the ECOWAS peace and security responses in the subregion. These historic colonial divisions coupled with the pursuit of strategic self-interests have often prevented the development and implementation of common values. In some cases, however, ECOWAS has co-operated on the basis of common values. The conflict management interventions in Liberia, Sierra Leone, Guinea Bissau and Cote d'Ivoire are a demonstrable track record of the development of common foreign and security policy. The main problem is the fact that the record of ECOWAS common foreign and security policies is based on ad hoc crisis management intervention responses dictated by the politics of 'do something now'.

However, there is the acknowledged view that the norm of mutual interdependence and peaceful co-existence is emerging and that these are inextricably linked to peace and democratic consolidation with the potential to create democratic zones of peace over time in the sub-region. In addition, there is the emerging norm of common identity, the identity of West African unity as the mechanism or instrument for the resolution of regional problems. The norm of sub-regional unity and co-operative ethos, despite the perennial problem of the colonial divide, provided the opportunity for ECOWAS countries 


\section{David J. Francis}

to 'do something' about the peace and security problems within the region, and to develop viable mechanisms for the pacific settlement of disputes and conflict management. There is the explicit realisation that the containment and management of armed conflicts and violence potentially create disincentives for violence amongst member states, thereby positively contributing to the reduction of potential conflicts in the sub-region. There seems to be a positive correlation between building regional structures and the opportunities for reduction and prevention of violent conflict.

ECOWAS has been challenged by a fundamental problem relating to differences in perception amongst member states on economic and security regionalism. This has presented considerable difficulties to ECOMOG operations. The majority of the Francophone and Lusophone states perceived ECOWAS as primarily an economic integration and development grouping and therefore had serious reservations about expansion into the regional peace, security and military domain. The Anglophone states however perceived ECOMOG as the security and military arm of ECOWAS' economic and political integration, arguing that collective regional resources should be allocated for the maintenance of regional peace and security. This has led to the perception of 'Two ECOWAS'. To ameliorate the negative effects of the divisive geo-politics on regional peacekeeping and conflict management activities, valuable lessons were learnt from the Liberian peacekeeping and intervention. Based on this and in mediating the resolution of the Sierra Leone conflict, ECOWAS made a sustained effort to engage with the Francophone countries. For example, Côte d'Ivoire played a vital role in negotiating and hosting the first peace agreement for Sierra Leone. Togo had a critical involvement in negotiating and hosting the Lomé Peace Agreement of 1999 that formally ended the civil war in Sierra Leone. Burkina Faso was also instrumental in facilitating the involvement of the RUF in the Lomé peace process and in the mediation of the civil war in Côte d'Ivoire. The engagement with the Francophone group considerably reduced the tensions and divisions in terms of a common approach to regional peace and security and also the concerns about the dominance of Nigeria.

In discussing the politics of ECOMOG operations in relation to its effectiveness in regional peacekeeping and conflict management, Maxwell Khobe argues 
that the governments of the troop-contributing countries often exercised considerable political control over their contingents, with deleterious operational implications. He explained that the ECOMOGForce Commander had no absolute operational command and control of the contingents, who were often deployed not according to the military appreciation of the Force Commander, but by their home governments. Therefore commanders of each contingent were answerable to both ECOMOG's Force Commander and their own Chief of Defence Staff and Defence Ministers - who were often more powerful voices. Drawing from his practical experience in ECOMOG operations, General Khobe posited that the divisive geo-politics meant that troop-contributing countries could not agree on the regional approach to peacekeeping and conflict management, for instance, the use of force, or when such force could be used and for what purpose. ${ }^{9}$ This led to a situation whereby some ECOWAS countries actively supported rebel factions and even made available their territories for military operations. As a military intervention force, ECOMOG had difficulties in operating a unified command and control structure due to its ad hoc nature and political elements that created the peacekeeping force. The considerable autonomy of the contingent commanders over the ECOMOG Force Commander, according to Khobe, led to situations whereby 'contingent units were pulled out of their areas of deployment without the approval or even the knowledge of the force commander, thus endangering the deployment of flanking contingents. Some contingents have also at times refused to come to the aid of other contingents without the clearance of their home governments' (Francis 2004:116). By all indications, this is a recipe for failure of regional peacekeeping and conflict management. In addition, ECOMOG operations have been plagued by all the usual problems faced by multinational peacekeeping and peace support operations, though the problems are far worse in the case of West Africa. These problems include language difficulties, lack of standardisation of equipment, different training standards, doctrines and staff procedures, poor sea and airlift capabilities, absence of vital air-to-ground support assets (in particular, ground attack helicopters more suited to the terrain), guerrilla warfare operations in West Africa, inadequate resources to deal with humanitarian problems, poor

9 Quoted in Adebi 2002. 


\section{David J. Francis}

liaison with international relief agencies, and inadequate logistical support for some contingents (Khobe 2000:4). General Khobe's seminal conclusion is a valuable outline explaining the problems and challenges that hinder the effectiveness of ECOWAS in peace and security.

\section{Nigeria's hegemonic leadership in ECOWAS peace and security}

Nigeria's leadership of ECOWAS and ECOMOG is crucial to the effectiveness of the regional organisation in peace and security. As the sub-regional hegemon, it was instrumental in the formation of ECOWAS and in the 1990s provided the politico-financial and military leadership to develop a regional collective peace and security system in the form of ECOMOG. Nigeria's preponderance in the sub-region in terms of size, population, military, economic and political resources has inextricably linked the country's national security to regional security. Three important developments have been the driving force for Nigeria's leadership role in West Africa.

Firstly, the Biafran civil war of 1967-70 and the role played by neighbouring countries, in particular, how they were used by extra-regional actors and powers as a staging post for support to the secessionist group. This was viewed by the government as an attempt to 'balkanise' the country, and it led to the realisation that the national security of Nigeria cannot be divorced from regional security and stability. It marked an important turning point in the political history of the country as it led to a paradigm shift in its post-independence foreign and security policy from 'isolationism' to 'intervention' in regional affairs. The post-civil war foreign policy therefore focused on three inter-related levels, i.e. promotion of regional security and stability through regional co-operation and integration, and leadership roles in African and international affairs. An important consideration was the intrusive role of France and the power politics with Nigeria for the dominance and control of West Africa. The motivation for the creation of ECOWAS was therefore to provide an instrument to promote Nigeria's foreign and security policy in West Africa as well as to limit the role of France in the sub-region, a region considered by Nigeria as its political, strategic and economic sphere of influence. 
Secondly, the discovery of oil and the OPEC (Organisation of Petroleum Exporting Countries) oil crisis of 1973, converted Nigeria into an indispensable oil producer for the West. Oil wealth provided the financial and economic resources to promote ambitious foreign and security policies, and the opportunity to flex its political and diplomatic muscles in regional, African and international affairs. With the end of the Cold War, Nigeria's political, military and economic influence and dominance have increased in West Africa, supported by unprecedented oil revenues and windfalls from the demands for energy during and after the Gulf Wars of 1990 and 2003. Nigeria is among the World top 10 oil producers and oil-rich countries, but Nigeria is vulnerable to global economic trends and fluctuations in oil prices. Moreover, domestic political instability and insurgent military activities targeting oil workers, installations and production facilitates have affected Nigeria's oil production and the revenue resources available for regional peace and security operations.

Thirdly, the civil war experience and oil wealth have led to the evolution of a strategic culture in Nigeria's foreign and security policy predisposed to interventionism in regional affairs. I have argued that the dominant interpretations of Nigeria's foreign and security policy have been based on neorealist approaches, and have to a very large extent neglected particular domestic motivations and imperatives such as traditions, history, geographical location, values, attitudes, national achievements, and patterns of behaviour, and I have shown how all these impact on foreign and security policy-making (Francis 2004:116). I further posit that a variety of Nigeria's interventions in West Africa, whether military or non-military, sometimes conflicts with its economic and strategic interests, which therefore raises the question of the continued validity of the dominant power-political interpretations of the country's foreign and security policy. In the analysis of Nigeria's hegemonic role in West Africa and its leadership in building regional peace and security systems, it is important to consider the impact of strategic culture as an explanatory variable in providing an understanding of how Nigeria has linked its national security to regional security and why it has developed the attitude and behavioural patterns that assume that it is its 'manifest destiny' to police and intervene in West Africa. The dominance of the military establishment in the post-independence history of 


\section{David J. Francis}

Nigeria and the particular military culture and its predisposition to the threat and the use of force in regional peace and security matters seem to suggest the prevalence of the strategic culture of pro-interventionism in the sub-region.

Nigeria's political, military and financial leadership of ECOWAS and ECOMOG's peacekeeping and conflict management interventions have been critical to the success, failure or effectiveness of the regional organisation's forays into peace and security issues. From Liberia to Sierra Leone and Guinea Bissau to Côte d'Ivoire, Nigeria's pivotal role has been crucial to the containment of these civil wars and the subsequent peace agreements. However, Nigeria has not been the only player. Other West African states and, in particular, the Francophone countries and external actors have played vital roles. The Bissau conflict was the first attempt by the Francophone states in West Africa to organise regional peacekeeping and conflict management deployment without the involvement of the dominant sub-regional player, Nigeria. But without Nigeria's leadership and other internal and external factors, ECOMOG IV's ceasefire monitoring and conflict stabilisation ended in failure.

The ECOMOG experience in regional peacekeeping and conflict management demonstrates the relevance of the role and contribution of sub-regional hegemons in the maintenance of regional peace and security. Despite reservations about Nigeria's preponderance, its dominant role continues in West Africa. Its presence and enforcement operations contributed to the management of the conflicts and the restoration of fragile stability. In general, the majority of West African states tend to accept Nigeria's leadership in regional peacekeeping, but equally resent its unilateral military intervention and 'gun boat' diplomacy. This illustrates that a regional collective security mechanism, led by a sub-regional hegemon, has to be sensitive to reservations about threats to sovereignty by member states. Concerns about Nigeria's preponderance and 'pax Nigeriana' by smaller states have been persistent. In fact, some states perceived ECOMOG as an instrument of Nigerian foreign and security policy. This provided opportunities for extraregional actors, with strategic interests in West Africa, to discourage some ECOWAS states from participation in the Nigerian-led regional peacekeeping force, hence undermining the effectiveness of ECOWAS in peace and security. 
In the post-Cold war era the security vacuum created in West Africa has given Nigeria increasing opportunities to play a dominant role in the maintenance of regional peace and security. But Nigeria's military capability is stretched in foreign and domestic deployments to contain ethno-religious instigated conflicts. In addition, the decades of poor socio-economic conditions and bad management of the economy have also weakened the resource base of Nigeria and in effect its ability to play an increasing role in regional peace and security. Furthermore, democratic governance in the post-military era of 1999 has introduced constitutional and democratic accountability constraints. For instance, troop deployment in regional conflicts now has to be approved by the Nigerian House of Representatives. Additionally, the casualties suffered by the Nigeria-led ECOMOG in regional peacekeeping and conflict management operations have become acrimonious domestic political issues. Increasingly domestic public opinion not only raises concerns about Nigerian casualties in foreign military adventures, but also questions the rationale of diverting millions of dollars from domestic socio-economic development to regional peace and security activities. This raises the issue of sustainability of regional peacekeeping and conflict management operations by largely underdeveloped and cash-strapped economies in West Africa. Based on the analysis of Nigeria's leadership role in both ECOWAS and ECOMOG, it is reasonable to conclude that without the involvement and commitment of the sub-regional hegemon, ECOWAS participation and effectiveness in regional peace and security activities will be considerably limited, bearing in mind that ECOWAS has no standing army nor any military logistical facilities and as such has to rely on member states, in particular, Nigeria, for troop contribution.

\section{External pivotal states / foreign powers and the UN in ECOWAS peace and security}

External actors, and in particular, external pivotal states and the UN are of vital importance in understanding the effectiveness of ECOWAS in peace and security. External support is central to the effectiveness of the ECOWAS-led peace and security initiatives. The US support in Liberia, Britain in Sierra Leone, CPLP in Guinea Bissau and France in Côte d'Ivoire, the UN and other key donor 


\section{David J. Francis}

agencies and intergovernmental institutions such as the EU, African Union, and Commonwealth were crucial in negotiating the civil war peace settlements, supporting ECOWAS political and diplomatic activities, ECOMOG's peacekeeping and peace enforcement operations, and post-war peacebuilding and reconstruction in West Africa. However, the conflict of interest of extraregional actors and Western governments involved in the management of civil wars in the region has created obstacles for troop deployment, reinforcement and logistical support for ECOMOG peacekeeping operations. Despite this, the general consensus at the level of the international community is that there is a need to support and capacitate the Africa-led approaches to managing and resolving conflicts on the continent. The prevailing view is that the challenges posed by contemporary globalisation, the war on terrorism and the regionalisation of domestic civil wars mean that wars and armed conflicts in Africa inevitably affect other parts of the world in diverse ways, hence it is in the interest of the West or the international community to support African approaches to African problems in peace and security.

The majority of the external powers intervening in peace and security in West Africa do so because of historic and colonial reasons. All the ECOWAS states have traditional bilateral military and defence arrangements with their former colonial masters. In crisis situations, the strategic response of the majority of ECOWAS states is to turn to their former colonial masters for help. This traditional response 'mentality' of ECOWAS states therefore creates a conflict of interest between ECOWAS regional response to peace and security and that of external pivotal states' unilateral interventions. For its part, the EU has longstanding historic links with West Africa through colonialism, bilateral political, socio-economic and commercial partnerships through the Accra Comprehensive Peace and the Cotonou agreements. Since 1996, the EU has contributed $\square 1.9$ million to support the peace and security activities of ECOWAS. The justification is that this is part of its conflict prevention and peacebuilding strategic policy framed as structural stability (European Commission 1996). But external interventions in West Africa have also been criticised because they have, in some ways, constrained or undermined the effectiveness of ECOWAS in regional peace and security. Though the EU's financial, political and diplomatic 
support has been welcomed, its peace, security and conflict related interventions have been rather disjointed and contradictory. ${ }^{10}$ In addition, external conflict and development interventions in West Africa have been generally criticised because they are often based on a short-term, quick fix and exit strategy orientation. They do not address the fundamental problems at the root of the conflicts, nor do they develop strategies with a long-term focus on durable peace and sustainable development. Furthermore, the majority of the conflict and development interventions are designed for the attention of international media and largely based on the notions of a liberal peace project, so that there is hardly any opportunity for domestic and local input into the external peace and security response activities. External actors therefore play a dual role, on one hand they contribute to and strengthen the effectiveness of ECOWAS peace and security and on the other hand, they potentially undermine the effectiveness of the regional organisation in peace and security.

The UN has been a critical and major player in West Africa and, as such its role is crucial to the understanding of the effectiveness of ECOWAS in peace and security. In the West African complex political emergencies, the UN has deployed a range of peacekeeping and peace support operations in Liberia, Sierra Leone, Guinea Bissau, and Côte d'Ivoire. It has done so in collaboration with external pivotal states and ECOMOG within a co-deployment framework. Despite the relative success of the UN peacekeeping and peace support to ECOWAS and ECOMOG in West Africa, the nature of some of the peacekeeping mandates considerably undermined any form of effectiveness. For example, the traditional peacekeeping mandate assigned to UNOMIL was not only unsuitable to the conflict situation in Liberia but also reflected a lack of appreciation of the challenges faced by peacekeepers deployed in a complex political emergency.

However, the co-deployment between UN and ECOMOG created a division of labour based on comparative advantages. UNOMIL and the SRSG mobilised political and diplomatic activities in support of the ECOWAS Peace Plan and conflict management in Liberia. In addition, the UN framework provided access

10 For detailed criticisms of the EU response to conflict, security and peacebuilding in Africa, see Gilbert 2007:41-49. 


\section{David J. Francis}

to financial and logistical resources, and also provided political legitimacy for ECOMOG's peace enforcement activities. Furthermore, UNOMIL provided peace support operations in organising and supervising, together with ECOWAS, OAU, EU and key western governments, parliamentary and presidential elections. The US provided the sum of US $\$ 25$ million for the Liberian electoral and post-war reconstruction. And on the other hand, ECOMOG undertook enforcement operations, disarmament of warring factions, monitoring of borders to police the arms embargo, and provision of security during general elections. The result of this co-deployment experiment, despite its limitations, according to Adebi (2002:83), was a 'string of success in every important aspect of the Liberian peace process: diplomacy, disarmament and elections'. The co-deployment strategy provided a new framework for burden sharing and sharing of responsibilities between the UN and regional organisations in the maintenance of international peace and security. Co-deployment peacekeeping in Liberia largely succeeded in stopping the killings, provided access for the delivery of humanitarian assistance and the disarmament, rehabilitation and re-integration of warring factions. Despite the limitations and dangers inherent in co-deployment, it has been lauded as a model for the future of peacekeeping in Africa (Adebi 2002:83). Kofi Annan, in support of the Liberian co-deployment, stated that 'we developed a new form of co-operation for the resolution of other conflicts whether in Africa or elsewhere' (Francis 2000:189). However, the co-deployment experiment could not function effectively as planned because of the existence of parallel command structures, and though UNOMIL was supposed to act in a supervisory role over ECOMOG, the military exigencies on the ground often dictated the nature of the supervisory role. As long as UNOMIL restricted itself to traditional peacekeeping in a complex conflict situation, ECOMOG as the primary peace enforcement agency often held the upper hand and invariably reduced UNOMIL to a secondary position. There was, in effect, no verifiable body to monitor the activities of ECOMOG, thus Adebi laments that 'the subordination of regional command structures to global authority was neither attempted nor achieved by UNOMIL' (Adebi 2000:83). 


\section{Quality of leadership of regional organisation}

Leadership of the regional organisation and lead nations, in particular, the dominant state, Nigeria, is key to the effectiveness of ECOWAS in peace and security. General Yakubo Gowan's leadership of Nigeria in the 1970s was crucial to the establishment of ECOWAS. Similarly, General Babangida's instrumental leadership led to the creation of ECOMOG. In the 1990s, it was the political leadership of key West African leaders, in particular, the then Nigerian military leader, General Babangida, that made it possible for ECOWAS to intervene in regional peace, conflict and security issues. As a military dictator, with preponderant military resources and might, financial capacity and political influence, General Babangida effectively directed the creation of ECOMOG, citing the imperative of Nigeria's foreign and security policy, as the justification for the establishment of the regional peacekeeping and intervention force. The rest of the ECOWAS member states were simply requested to support the 'regional initiative' and those reluctant to do so, mainly Francophone states, were cajoled and 'bribed' with preferential oil shipments to convince them to join the regional military adventure.

How does leadership of ECOWAS in peace and security translate on the ground in practical terms? Between 1990 and 2003, ECOWAS had two proactive Executive Secretaries in the persons of Dr. Abass Bundu and Dr. Mohamed Ibn Chambers. The quality of their leadership made it possible to translate the political commitments of the heads of state and government of ECOWAS into practical military and operational peacekeeping and peace support operations deployment, including the effort to mediate political settlement of the civil wars in West Africa. Both Executive Secretaries have been involved in the civil war peace settlements that led to the management and political settlement of the wars in Liberia, Sierra Leone and Côte d'Ivoire. It is perhaps at the military level of ECOMOG peacekeeping and conflict management that the quality of leadership is more important. Between 1990 and 1998, ECOWAS appointed nine ECOWAS Field Commanders, all with varying degrees of effectiveness in the implementation of the ECOWAS peace and security mandate in each of the war-torn countries. After the debacle of September 1990 whereby the de facto 


\section{David J. Francis}

president of Liberia, Samuel Doe, was captured under the watchful eyes of ECOMOG and killed by the INPFL (Independent National Patriotic Front of Liberia), Lt. Gen. Quainoo (Ghanaian) was replaced by Maj. Gen. Dongoyaro (Nigerian), who rapidly developed a reputation as a no-nonsense military peace enforcer in Liberia. Despite the fact that ECOMOG's initial peacekeeping deployment was given a Chapter VI mandate, Gen. Dongoyaro was often prepared, based on the military imperatives on the ground, and without the approval of his political masters, to expand the mandate of ECOMOG to peace enforcement, in a desperate bid to bring some level of stability and order to the war-ravaged country. Similarly, and at the height of the bloody civil war in Sierra Leone, Maj. Gen. Victor Malu was deployed between December 1996 and January 1998 to lead the peace enforcement operations of ECOMOG in Sierra Leone. It is generally acknowledged in Sierra Leone that the quality of his military leadership of ECOMOG during this period forced the RUF to the negotiating table and the reinstatement of the government of President Kabbah. However, academics are divided as to whether the agency is more important than structure in the effectiveness of not only foreign policy but also regional organisations in responding to peace and security issues. ${ }^{11}$

\section{Conclusion}

In this article, I have critically outlined the evolution of ECOWAS and its expansion into the peace and security domain in the form of ECOMOG peacekeeping and peace support operations. But if ECOMOG is to serve as a permanent regional peacekeeping and conflict management mechanism and become part of the proposed African Union African Standby Force (ASF), there are valuable lessons to learn from its West African operations. For instance, the ad hoc nature of its deployment did not provide time enough for proper logistical planning and resourcing of the operations. The improvisatory nature of its creations also has implications for the lack of clarity of its mandate, especially relating to peacekeeping and peace enforcement. The 1999 Protocol on Regional

11 For further analysis of the agency-structure debate in international relations, see Brown 1997:73-84. 
Peacekeeping, Conflict Management and Security Mechanism was therefore an attempt to respond to the problems, challenges and opportunities arising from the ECOMOG experience since 1990. But the adoption of the protocol did not have any conceivable impact on the management of the conflicts after 1999.

A question raised by many political analysts and media commentators focuses on the real reasons that motivated the ECOWAS leadership to venture into the difficult arena of regional peacekeeping and conflict management. This question is at the centre of 'why' and 'how' ECOWAS can be effective in regional peace and security issues, in particular, if it is driven by the whims and preferences of the dominant state - Nigeria. A more persuasive reason for the ECOWAS unusual regional 'collective' peacekeeping or 'coalition of willing states', was the threat posed by rebel insurgency to the security and survival of the regimes in the sub-region. Insurgency or guerrilla warfare was a relatively new phenomenon in post-Cold War West Africa. It presented an alternative to military coups and access to state power and its patrimonial resources. Since the majority of the regimes were of questionable legitimacy and democratic credentials, the rally of ECOWAS leaders under the umbrella of 'regional collective security' and peacekeeping in Liberia was an attempt to discourage the 'power of the Liberian example' and, by the same token, protect and secure the survival of their regimes. The official view was that ECOMOG was acting within its constituted mandate as provided for in the 1981 defence protocol, by responding to a request from a member state invaded by 'foreign-backed' forces. A more credible reason was the perceived threat to the national security of Nigeria and the implications for its foreign and security policy. The Nigerian president, General Babangida, captured the strategic culture of pro-interventionism in a statement on the Liberian crisis in 1990 when he stated that 'When certain events occur in the sub-region depending on their intensity and magnitude, which are bound to affect Nigeria's politico-military and socio-economic environment, we should not stand by as helpless and hopeless spectators' (Francis 2001:42). Nigeria's leadership was also motivated by the need to limit, contain and discourage some Francophone countries that were supporting the NPFL rebel insurgency in Liberia. Always looking for an opportunity to demonstrate its benevolent hegemonic leadership in West Africa, the perceived international neglect of Africa also provided the 
international environment for Nigeria to develop and put into practice the much-touted 'Try Africa First' approach to conflict management and resolution.

Therefore in evaluating ECOWAS effectiveness in regional peace and security issues, there are key issues worthy of consideration and they are: the geopolitics of West Africa and its constraints on the development and practice of common foreign and security policies; the leadership role of Nigeria; the role and contribution of extra-regional actors such as the former colonial powers and the UN, and the quality of leadership of both ECOWAS and ECOMOG.

\section{Sources referred to}

Adebi, A. 2002. Muddling through: An analysis of the ECOWAS experience in conflict management in West Africa. In: Laasko, L. ed. Regional integration for conflict prevention and peace building in Africa: Europe, SADC and ECOWAS. Helsinki, Department of Political Science, University of Helsinki.

Brown, Chris 1997. Understanding international relations. London, Macmillan.

Deutsch, Karl Wolfgang, Sidney A. Burrell and Robert A. Kann 1957. Political community and the North Atlantic area. Princeton, Princeton University Press.

ECOWAS Standing Mediation Committee 1990. Decision A/DEC.1/8/90 on the ceasefire and establishment of an ECOWAS Ceasefire Monitoring Group for Liberia.

European Commission 1996. The European Union and the issue of conflicts in Africa: Peacebuilding, conflict prevention and beyond. Conflict prevention: Overview, 6 March 1996. Available from: <http://ec.europa.eu/comm/external_relations /cfsp/cpcm/cp.htm>

Francis, D. 2000. ECOWAS Cease-fire Monitoring Group (ECOMOG): A new security agenda in world politics. In: Bakut, Simon and Sagarika Dutt eds. Africa towards the millennium: An agenda for mature development. London, Palgrave. pp. 177-202.

Francis, D. 2001. The Politics of economic regionalism: Sierra Leone in ECOWAS. Aldershot, Ashgate.

Francis, D. 2004. Nigeria. In: Glenn, J., D. Howlett and S. Poore eds. Neorealism versus strategic culture. Aldershot, Ashgate.

Francis, D. 2006a Linking peace security and developmental regionalism: Regional economic and security integration in Africa. Journal of Peacebuilding \& Development, 2 (3).

Francis, D. 2006b. Uniting Africa: Building regional peace and security systems. Aldershot, Ashgate.

Gilbert, M. 2007. Monitoring a region in crisis: The European Union in West Africa. Chaillot Paper No. 96, Jan 2007. 


\section{Peacekeeping in a bad neighbourhood: ECOWAS in peace and security in West Africa}

Haas, Ernst 1994. Collective conflict management: Evidence for a new world order? In: Kratochwil, Friedrich V. and Edward D. Mansfield eds. International organization: A reader. New York, Harper Collins. pp. 237-256.

Kaplan, R. 1994. The Coming Anarchy. Atlantic Monthly, February 1994.

Keohane, Robert 1982. The demand for international regimes. International Organisation, 36, pp. 325-356.

Keohane, Robert 1994. International institutions: Two approaches. In: Kratochwil, Friedrich V. and Edward D. Mansfield eds. International organization: A reader. New York, Harper Collins.

Khobe, M. 2000. The evolution and conduct of ECOMOG operations in West Africa. In: Institute for Security Studies, Boundaries of peace support operations. ISS Monograph No. 44, February 2000.

Mearsheimer, J. 1994/5. The false promise of international institutions. International Security, 19 , pp. 5-49.

Nwachukwu, Ike 1991. Nigeria and the ECOWAS since 1985: Towards a dynamic regional integration. Enugu, Fourth Dimension Publishers.

Olawunmi, B. 1998. Resolving the military stand-off in Guinea Bissau. The West African Bulletin No. 6, October 1998, pp. 6-18.

United Nations Development Programme (UNDP) 2006. UNDP Human Development Report 2006. Available from: <www.hdr.undp.org >

United Nations Security Council 1999. UN Document S/1999/741, 1 July 1999. New York, UN Security Council.

\section{Sources also consulted}

Adebajo, A. 2002. Building peace in West Africa: Liberia, Sierra Leone and Guinea-Bissau. Boulder, Lynne Rienner.

Alagappa, M. and Inoguchi, T. eds. 1999. International security management and the United Nations. Tokyo, UN University Press.

Bernanm, Eric and Katie Sams 2000. Peacekeeping in Africa: Capabilities and culpabilities. Geneva, UNDIR.

Bundu, Abass 2001. Democracy by force? A study of international military intervention in the conflict in Sierra Leone from 1991 - 2000. Boca Raton, FL, Universal Publishers.

Buzan, Barry and Ole Waever 2003. Regions and power: The structure of international security. Cambridge, Cambridge University Press.

Clapham, C. 1998. Degrees of Statehood. Review of International Studies, 24 (22), pp. 143-157.

Debiel, Tobias, Dirk Messner and Franz Nushceler 2007. Global Trends 2007: Vulnerability and human security in the $21^{\text {st }}$ century. Bonn, Development and Peace Foundation. 


\section{David J. Francis}

ECOWAS 2008. Achievements of ECOWAS: Regional peace and security. Available from: $<$ www.sec.ecowas.int/sitecedeao/english/peace.htm>

ECOWAS 1997. Final communiqué of the meeting of ECOWAS Council of Ministers, Abuja: ECOWAS, 28 August 1997, Decision A/DEC/7/8/97, Abuja, ECOWAS Secretariat, 29 August 1997.

Imobighe, T. 1994. ECOWAS Defence Pact and regionalism in Africa. In: Kratochwil, Friedrich V. and Edward D. Mansfield eds. International organization: A reader. New York, Harper Collins.

Nathan, L. 2006. SADC's uncommon approach to common security: 1992-2003. Journal of Southern African Studies, 32 (3), pp. 614-618. 